\title{
Asset Restructuring Strategies in Bank Acquisitions: Evidence from the Italian Banking Industry ${ }^{*}$
}

\author{
Pietro Alessandrini \\ LABIS - Dipartimento di Economia \\ Università Politecnica delle Marche \\ Giorgio Calcagnini \\ Facoltà di Economia \\ Università di Urbino "Carlo Bo" \\ Alberto Zazzaro \\ LABIS - Dipartimento di Economia \\ Università Politecnica delle Marche
}

\begin{abstract}
One of the most lively debated effects of banking acquisitions is the change in lending and asset allocation of the target bank in favour of transactional activities, at the expense of small and informational opaque borrowers. These changes may be the result of two distinct restructuring strategies of the asset portfolio of the bidder bank. An asset cleaning strategy (ACS), in which the acquiring bank makes a clean sweep of all the negative net present value activities in the portfolio of the acquired bank, and an asset portfolio strategy (APS), in which the acquiring bank permanently changes the portfolio allocation of the acquired bank. In this paper we focus on Italian bank acquisitions and test which asset restructuring strategy was predominantly pursued over the period 1997-2003. Moreover, we estimate both a model for the whole Italian banking industry and a model for the acquired banks located in economic backward Southern regions. At the national level we find evidence of a primacy of ACSs over APSs. When we concentrate on bank acquisitions that occurred in the Mezzogiomo (Italy's Southern regions), evidence seems to reverse, i.e. APSs dominate over ACSs.
\end{abstract}

Keywords: Bank acquisitions; Asset restructuring strategies; Small businesses lending.

JEL codes: G21; L22

\footnotetext{
* Correspondence to: Alberto Zazzaro, Dipartimento di Economia, Università Politecnica delle Marche, Piazzale Martelli 8, 60121 Ancona, Italy E-mail: a.zazzaro@univpm.it, Tel.: +39 0712207086. Fax: +39 0712207102. We thank Riccardo De Bonis, Don Hester, Riccardo Lucchetti, Alberto Niccoli, Erasmo Papagni and participants at the conference "International Comparisons in the Financing of SMEs in Developed Countries" (Warwick Business School, 2006) for commenting upon a previous version of the paper.
} 


\section{Introduction}

One of the most lively debated effects of banking mergers and acquisitions is the change in lending and asset allocation of the target bank in favour of transactional activities, at the expense of small and informational opaque borrowers (Berger et al. 1999; Alessandrini et al. 2003). These changes may be the result of two distinct restructuring strategies of the asset portfolio of the bidder bank. An asset cleaning strategy (ACS), in which the bidder bank makes a clean sweep of all the negative net present value activities in the portfolio of the target bank; and an asset portfolio strategy (APS), in which the bidder bank permanently modifies the asset allocation of the target bank. In turn, the portfolio strategy may have two motivations. First, the bidder bank may want to improve upon the non-optimal asset allocation of the target bank, by refocusing the lending portfolio of the latter towards a certain type of borrower, and by expanding previously undersized service activities (henceforth, asset portfolio reassessment strategy - APRS). Second, the reshaping of the lending portfolio of the target bank may be associated with changes in its marginal costs and revenues due to the transformations in the size, organisation and competitive position resulting from the consolidation (henceforth, asset portfolio consolidating strategy - APCS).

All of these restructuring strategies aim to attain the first-best asset allocation. However, their consequences in terms of social surplus can be substantially different.

Under ACS, the cut in (small business) lending would concern only negative net present value projects, inefficiently funded in the past by the acquired bank. It would, thus, determine an increase in social surplus.

Under APRS, changes in the lending portfolio are those that the target bank should have introduced to attain the optimal asset allocation, even in the absence of consolidation. It is also likely that these changes will hurt some positive net present value borrowers, by interrupting relationships with other banks difficult to rebuild in the short run. However, as in the case of ACSs, APRSs definitely end up increasing social surplus by improving upon a previous asset misallocation. 
Under APCS, transformations in the organisational structure that usually follow an acquisition affect the shape of the cost and revenue functions of the target bank and, therefore, its optimal assets and liabilities composition. This means that the changes induced in the asset portfolio of the acquired bank by an ACPS are not necessarily accompanied by an increase in social surplus.

Which asset restructuring strategy is chosen by the bidder bank may depend on many factors. One of these is certainly the economic and social environment in which the bidder and the target bank operate. In particular, the importance of APCSs tends to increase as the differences in asset allocation, credit policy, and way of "thinking" between the bidder and the target bank increase . The consolidation of two radically different banking contexts, for example, exacerbates agency problems between the central and the local level of the new institution, and this may raise the relative cost of relational activities.

In the real world, however, bidder banks usually pursue several asset restructuring strategies at the same time. Therefore, it is difficult to empirically identify them. One way is to exploit the different time profile of each strategy and the relative different effects on banks' expected profitability. More specifically, we can argue that the ACS affects the target bank's balance sheet very soon after the consolidation date, while APSs require more time to be successfully implemented. Moreover, it is straightforward to argue that an APRS, by settling some preconsolidation inefficiencies, increases the expected profitability of the target bank. In contrast, an APCS has in principle ambiguous effects on expected profitability of the target bank, by responding to changes in its optimal asset allocation.

While there exists a large body of economic literature on the effects of banking consolidation on small business lending, less empirical work is dedicated to a systematic analysis of restructuring strategies in bank consolidation.

As is well known, consolidation may proceed by means of mergers or acquisitions. In mergers, two or more banks consolidate their charters. In acquisitions, a controlling stake of one bank (the acquired or passive bank) is purchased by another bank (the acquirer or active bank), but both 
banks retain their separate charters within the same banking group. In this paper we focus on Italian bank acquisitions and test which, if any, asset restructuring strategy was predominantly pursued over the period 1997-2003.

The Italian banking industry is an important case-study to analyse the asset restructuring strategies in bank consolidations. First, in Italy the number of banking consolidation deals, as well as their market value, was one of the highest in Europe (European Central Bank 2000, 2005). Second, the consolidation process led to the almost complete disappearance of an autonomous banking system in the Southern part of the country (the so-called Mezzogiorno), that is characterised by deep economic and social differences with respect to the Northern-Central regions. Third, the Italian economy is characterised by a financial system dominated by banks and an industrial system based on small- and medium-sized firms. This economic configuration makes any dismissal policy of small business lending potentially full of negative consequences for the local economies. Moreover, it provides ideal grounds to establish whether and how restructuring strategies vary with the economic environment in which target banks operate.

Our focus on banking acquisitions may be justified on two grounds. First, banks participating in an acquisition keep their assets and liabilities distinct, and this allows us to directly assess the restructuring effects of the deal by observing how the balance-sheet ratios of the acquired bank change over time. Second, in Italy acquisitions have definitely represented the major form of consolidation in the banking industry. In terms of intermediated funds, during the decade 19932003 the value involved in acquisitions was 3.7 times than that involved in mergers (3.9 if we exclude mergers involving credit cooperative banks). ${ }^{1}$

Empirically, we take a novel approach from the point of view of the banking consolidation literature and estimate a dynamic panel model by using the system GMM estimator (Arellano and Bover 1995; Blundell and Bond 1998). To assess which was the leading restructuring strategy in bank acquisitions, we compute both short- and long-run effects by distinguishing young acquired banks (banks involved in an acquisition during one of the last three years from the date of the deal)

\footnotetext{
${ }^{1}$ These figures are from Messori and Zazzaro (2003) and Banca d'Italia (2005).
} 
from old acquired banks (banks involved in an acquisition more than three years before the date of the deal). Moreover, we estimate both a model for the whole Italian banking industry and a model for the acquired banks located in Southern regions.

Summing up our main conclusions, at the national level we find evidence of a primacy of ACSs over APSs. When we concentrate on bank acquisitions that occurred in the Mezzogiorno, evidence seems to reverse and APSs dominate over ACSs. Moreover, in this case we find some evidence inconsistent with APRSs.

The rest of the paper is organised as follows. Section 2 reviews the empirical literature related to our analysis. Section 3 discusses our empirical strategy. Section 4 presents data, variables and econometric methodology, while section 5 reports our empirical findings. Section 6 concludes.

\section{Related Literature}

Our paper is related to two strands of the empirical research in banking literature: (A) studies on the consequences of consolidation for the lending policies of the involved banks; (B) studies on the effects of organisational structure on banking performance.

\section{A. Banking consolidation and small business lending}

A large number of papers have addressed the issue of the consequences of banking M\&As for credit allocation and in particular for the availability of credit to small businesses. All these studies start from two findings that have proved to be quite robust in many countries (Berger and Udell 1998). First, small businesses rely more on bank credit than do large firms. Second, large banks devote a lower proportion of their lending activity to small businesses than small banks. Together, these findings seem to suggest that small businesses should experience a reduction in the overall availability of external finance as a consequence of the consolidation of two banking institutions.

However, M\&As are associated with other effects that could counterbalance the negative impact of the increase in lender size. For instance, the propensity to lend to small businesses could 
be positively affected by the efficiency gains of M\&As (Berger, Demsetz and Strahan 1999), by a higher risk diversification of the consolidated bank (Strahan and Weston 1998) and by the establishment of an internal capital market (Houston and James, 1998). Moreover, the reaction of other banks serving (or entering) the same market, that could tap some borrowers dropped by the consolidated bank, should also be taken into account (Berger et al. 1998; Goldberg and White 1998).

The available empirical evidence confirms this ambiguity by presenting a complex picture in which the effects of M\&As on small borrowers depend on the type and the size of institutions involved and on the economic environment in which the operation occurs. Findings from both the U.S. and the Italian banking industries seem to show that consolidations involving large or out-ofstate banks lead to a reduction in small businesses lending, whereas those between two small or instate banks often have the opposite effect on loans to small firms (Keeton 1997; Berger et al. 1998; Cole and Walraven 1998; Peek and Rosengren 1998; Sapienza 2002). Other studies have estimated how small business lending in a local market is affected by the total consolidation activity that occurred in that market. Avery and Samolyk (1999) find that the U.S. banking consolidation adversely affected small business lending in urban markets, but not in rural markets. Bonaccorsi and Gobbi (2001) find that, in Italy, only mergers negatively affect loans to small firms, and that this effect tends to disappear over time.

Berger et al. (1998), Peek and Rosengren (1998); Focarelli et al. (2002), Sapienza (2002), Bonaccorsi and Gobbi (2003) and Alessandrini et al. (2005) provide some evidence on the asset restructuring strategies followed by bidder banks in consolidation deals.

To evaluate the effects of banking consolidations on small business lending, Berger et al. (1998) estimate a model of credit allocation for all banks included in their sample. Starting from the amount of lending predicted by the model for different situations, Berger et al. separate static, restructuring and direct effects. The static effect compares the lending propensity of the consolidated bank with that of the same bank before the deal. The restructuring and the direct effects identify changes in credit allocation due the structural transformations of the target bank, 
similarly to what we labelled APCS. Surprisingly, they find that only the static effects penalise small firms, whereas restructuring and direct effects determine a reallocation of credit in favour of small firms at the expense of large firms. In the case of both in-state and out-of-state acquisitions, the static effect is offset by restructuring and direct effects and the total impact on small business lending is positive.

Peek and Rosengren (1998), consistent with our APCS, find evidence that the bidder bank tends to rearrange the lending portfolio of the target bank by driving the share of small business lending of the latter towards its own pre-merger levels. Sapienza (2002) confirms the importance of APSs in Italian bank consolidations. Specifically, using data on individual bank-firm relationships, she finds that the probability that the target bank will drop borrowers is unrelated to size, profitability and other observable firm characteristics. The importance of APSs is further established by Alessandrini et al. (2005) with data at the bank level. Namely, consistent with the APCS hypothesis, they find that in Italy the affiliation with a banking group has long-term effects on banks' performance (in terms of small business lending, loan growth, credit allocation, bad loans and profitability), but only for banks headquartered in less developed Southern regions. By contrast, Bonaccorsi and Gobbi (2003), by using data at the firm level, found that the reduction in corporate loans is limited to firms that have excess credit availability. From our point of view, therefore, Bonaccorsi and Gobbi's results suggest a dominance of the ACS over the APS.

Close to our analysis, but with the use of a different database from ours, Focarelli et al. (2002) utilised Italian bank data to analyse the short- and long-run effects of M\&As on balance-sheet indicators of target banks. By estimating a static fixed effects panel model over the 1985-1996 period, they find a permanent effect of consolidation deals on the asset allocation of merged and acquired banks. According to our classification, their findings are in favour of a dominance of APSs over ACSs. Specifically, their econometric analysis for merged (acquired) banks shows a permanent increase in fees from services (however only significant in the case of mergers), a permanent reduction of loans to small firms and a permanent increase (decrease) in other loans. When they 
look at banks' profitability, they find unambiguous evidence in favour of a permanent increase both in Return on equity (Roe) and Return on assets (Roa) before taxes. The increase is stronger in the case of acquired banks and suggests that the reshaping of the target banks' portfolios may be due both to a pre-consolidation misallocation of credit and to a post-consolidation change in their optimal asset allocation.

In this paper, we improve on Focarelli et al. (2002) in two major ways. First, we explicitly introduce dynamics into the analysis by estimating a dynamic panel model by means of the system GMM estimator. Second, as in Alessandrini et al. (2005), we try to test how the economic environment in which target banks operate affects the restructuring strategy pursued by the bidder bank. Specifically, we estimate a model comparing the performance of acquired banks headquartered in Southern and less developed Italian regions with those of autonomous banks headquartered in the same regions. Moreover, we consider a different period of time (1993-2003) and a sample that also includes cooperative banks.

\section{B. Organisational structure and banking performance}

A growing strand of the banking literature focuses on organisational issues. These contributions emphasize the decisive role of banks' organisational structures for portfolio allocation and small business lending, instead of banks' size per se. The importance of organisational features is motivated by a pervasive phenomenon: the asymmetrical distribution of information within organisations.

Information on local borrowers is actually in the hands of the local loan officer and most of it is soft, and not easily communicable to, and verifiable by, senior managers of the bank. It is the loan officer that has personal contacts with the borrower, lives in the same community, knows people and firms who do business with the latter. It is on her/his efforts in gathering information and investing in community-specific human capital that the capacity of the bank to select good projects depends. All these elements provide the loan officer with unique informational capital, which is not 
easily transferable to the upper echelons of the banking organization. Building on the literature concerning the economics of organisations, it is easy to realise that the informational rents of local loan officers have many consequences for bank behaviour and performance.

First, where the preferences of local and senior managers differ and bank-specific investments by the former may be carried out, agency and hold-up problems arise. In such cases, parent banks have to cope with an organisational trade-off between delegation and control (Stein 2002; Novaes and Zingales 2004). The solution to this trade-off may depend on a number of factors. However, whatever the combination of delegation and control, significant organisational diseconomies arise in which, everything else being equal, the latter end up reducing the profitability of relational lending. This is above all true in less developed regions, far removed from the headquarters of the parent bank, where lending is heavily based on soft information about borrowers, usually small and informationally opaque.

A second channel through which organisational complexity of the bank affects the optimal asset allocation exists in the "influence activities" which loan officers carry out in their attempt to affect the decisions of senior managers on the distribution of resources and power within the organisation (Milgrom 1988; Milgrom and Roberts 1990). Going back to a remark made by Meyer et al. (1992), one can conjecture that the motivations for influence activities are particularly keen when a previously autonomous bank is affiliated to a banking group or when the local office and the parent bank are located in very different economic environments, and the former focuses its lending on small businesses based on soft information.

There is a variety of types of evidence that all seem to confirm the importance of agency and influence costs in banking organizations. For example, managers of subsidiaries or branches usually conduct only a preliminary screening of loan applications by following well-defined standardized rules, while the final decision on loans is left to managers of the head office (Berger and Udell, 1989; Nakamura, 1994; Keeton, 1995; Liberti 2005). In addition, Liberti (2004) finds that empowering local managers increases the effort they devote to screening and monitoring 
borrowers, and improves the performance of the bank. Liberti, however, does not control for the resources that the parent bank spends in ex-post loan reviewing activities. The latter, as shown by Udell (1989), seem to have a strong positive correlation with the organisational complexity of the bank and the degree of autonomy of local managers.

Berger and DeYoung (2001; 2002), instead, concentrate on the efficiency costs of agency problems within a multi-bank holding company. They find that the cost and profit efficiency of parent and affiliated banks are positively correlated, and that this correlation reduces with an increase in the geographical distance between the two institutions. The cost of friction between local officers and senior managers is confirmed by Klein and Saidenberg (2005) who find that the bank holding company value, as measured by the market-to-book equity ratio, reduces with the diversity of bank subsidiaries in terms of size and lending.

Other studies concentrate on the effects of organisational diseconomies on asset allocation. Keeton (1995) finds that banks owned by out-of-state multi-bank holding companies employ a lower share of their deposits in small business lending than banks owned by in-state holding companies. In contrast, Whalen (1995) finds that for banks affiliated with out-of-state groups the proportion of small business loans is higher and the interest rates charged lower than those observed for independent local banks and in-state group affiliates. Berger et al. (2005) provide evidence that large banks lend comparatively more to less informationally opaque borrowers. Similarly, Cole et al. (2002) find that the lending decisions of large banks rely more on hard information rather than personal relationships. In addition, Carter et al. (2004) and Carter and McNulty (2005) find that net return on small business lending is lower for large banks than for small banks, confirming that the former have a disadvantage in lending to small businesses.

\section{The empirical model}


When the majority of bank shares and the control of an institution is transferred to another bank, the asset portfolio of the acquired bank usually goes through a deep restructuring process, favouring some assets at the expense of others.

The reasons behind restructuring may be diverse. To illustrate, consider the optimal asset portfolio of the target bank just before the date of the acquisition, say at time $t$. It is composed by $n$ assets in proportion $a_{j}$, with $j=1 \ldots n$, so as to equal expected returns for each of them

$$
a_{b a}=\left[\begin{array}{cccc}
* & { }^{*} & & \\
a_{1 b a} & a_{2 b a}^{*} & \ldots & a_{n b a}
\end{array}\right]
$$

where the subscript $b a$ stands for before-acquisitions, and asterisks identify the optimal asset shares.

The actual composition of the asset portfolio of the target bank at time $t$ can be different from the optimal one because of an ex-ante misallocation. Apart from misallocation, a proportion $x_{j} \geq 0$ of each asset can prove to be at a loss, so that the portfolio of the target bank can be identified by the vector:

$$
a_{t}=\left[\begin{array}{llll}
a_{1 t} & a_{2 t} & \ldots & a_{n t}
\end{array}\right]=\left[\begin{array}{llllllll}
a_{1 t}^{w} & a_{2 t}^{w} & \ldots & a_{n t}^{w} & a_{1 t}^{u} & a_{2 t}^{u} & \ldots & a_{n t}^{u}
\end{array}\right]
$$

where $a_{j t}^{w}=\left(1-x_{j}\right) a_{j t}$ is the ex-post worthy share of the asset $j$ and $a_{j t}^{u}=x_{j} a_{j t}$ the unworthy share.

After the acquisition deal, the optimal unit portfolio of the acquired bank is:

$$
a_{p a}=\left[\begin{array}{llll}
a_{1 p a}^{*} & a_{2 p a}^{*} & \ldots & a_{n p a}^{*}
\end{array}\right]
$$

where the subscript $p a$ stands for post-acquisitions.

Now, the acquiring bank can be in the presence of one or more of the following circumstances that call for an asset restructuring.

The first circumstance is an ex-post portfolio misallocation, where some assets of the acquired bank are committed to unworthy borrowers or other activities, that is, $a_{j t}^{u}>0$ for some $j$. In this case, the acquiring bank will start an asset cleaning strategy (ACS), with the objective of sweeping clean the unworthy assets of the acquired bank and improving its profitability. 
The second circumstance is an ex-ante portfolio misallocation, where the asset allocation of the acquired bank at time $t$ is non optimal, that is, $a_{j t} \neq a_{j b a}^{*}$ for some $j$. In this case, the acquiring bank will start an asset portfolio reassessment strategy (APRS), trying to bring the composition of the acquired bank portfolio towards its optimal before-acquisition structure.

The third situation is a change in the optimal portfolio. Indeed, the transformations in the size, organisation and competitive position of the acquired bank, that occurred as a consequence of the acquisition and the participation in a holding company, tend to change the composition of its optimal asset portfolio, that is, $a_{j p a}^{*} \neq a_{j b a}^{*}$ for some $j$. In this case, the acquirer should pursue an asset portfolio consolidating strategy (APCS), with the objective of reshaping the portfolio of the acquired bank in line with its new asset costs and revenues. The composition of the portfolio of the acquired bank at time $t+k$ is therefore equal to the composition of its portfolio at the acquisition date plus the changes associated with the three strategies actually implemented after $k$ years from the acquisition.

The fact that ex-post misallocation, ex-ante misallocation and the transformation of the optimal portfolio can take place all together, makes it very difficult to discern, on the basis of only indirect information, whether a predominant asset restructuring strategy occurred and which one specifically. In this paper, we suggest that asset restructuring strategies may be identified by looking at the time pattern of the changes which occurred in the asset allocation and profitability of the acquired bank.

In fact, different asset restructuring strategies tend to affect target banks' balance-sheets diversely, as synthesised in table 1. The ACS implies no changes in the optimal portfolio of the target bank. Therefore, it can be implemented very soon after the consolidation and does not affect the long run asset allocation of the target bank. By contrast, APSs need more time to be elaborated and successfully implemented. We expect that the effects of APSs will not be immediate, but that they have a permanent influence on the asset composition of the target bank. Finally, to distinguish between APRS and APCS we can look at the effects on banks' expected returns. Indeed, when the 
changes in the lending portfolio are imposed by the pre-acquisition inefficiencies of the target bank (i.e., under APRS), the effects on banks' expected net returns are positive. By contrast, in the case of APCS we compare two optimal asset allocations: the asset allocation of the target bank before the acquisition and after the organisational transformations associated with the deal. Therefore, keeping bank costs and efficiency constant, in the APCS case a priori we can say nothing on how expected returns will change following the acquisition.

\section{[Insert table 1]}

To test for the presence of ACS, APRS and APCS effects, we specify a simple dynamic model where the dependent variable depends upon: its lagged value, variables measuring banks' size and their market power, and a set of dummy variables describing their regional location (Southern regions versus Northern and Central regions) and their status of acquired or autonomous (not acquired) banks ${ }^{2}$. The inclusion of the lagged value of the dependent variable aims to capture the path-dependent component of banks' asset allocation. Acquisitions include all the cases in which a holding company or another bank belonging to a multi-bank holding company (MHC) acquires the majority of shares of the target bank. Therefore, the latter becomes a member of the same banking group of the acquirer, but it remains a separate entity with its own charter. Acquired banks are then divided into old and young categories to distinguish transitory from permanent effects.

The basic equation we estimate is:

$$
\begin{aligned}
y_{i t}= & a+b_{1} y_{i t-1}+b_{2} \text { SIZE }_{i t}+b_{3} \text { MARKET POWER }_{i t}+b_{4} \text { SOUTH }_{i t} \\
& +b_{5} \text { YOUNG ACQUIRED }_{i t}+b_{6} \text { OLD ACQUIRED } \\
i t & +\lambda_{i}+\phi_{t}+\varepsilon_{i t}
\end{aligned}
$$

where $y$ stands for a specific balance-sheet ratio (to be specified below), $i$ is for the bank and $t$ for the time period. Finally, $\lambda_{i}$ are unobserved bank-level effects, $\phi_{t}$ are time dummies, and $\varepsilon_{i t}$ are

\footnotetext{
${ }^{2}$ When the parent of a MHC is a holding company, we consider the lead bank of the MHC to be autonomous.
} 
observation-specific error terms where $E\left[\lambda_{i}\right]=E\left[\varepsilon_{i t}\right]=0, E\left[\lambda_{i} \varepsilon_{i t}\right]=0$ and $E\left[\varepsilon_{i s} \varepsilon_{i t}\right]=0$ for any $i$, $t$ and $s$.

While the exact description of the variables included in (1) will be analyzed below in section 4, here we can note that autonomous (independent and parent) banks is the benchmark category with which the other categories of banks, as identified by our dummy variables, are compared.

As a second step, we investigate if the location of the acquired bank affects the asset restructuring strategies pursued by the acquirer. Banks headquartered in economically backward regions lend, on average, to less worthy borrowers and usually have higher shares of non performing loans than banks located in developed regions. Therefore, the former call for more drastic ACS than other banks. But banks located in economically backward regions are also usually less efficient and less compelled by competition to oppose political and lobbying pressures to misallocate credit. Therefore, it is very likely that, once acquired, they are subjected to drastic APRSs. At the same time, lending relationships in economically backward regions are heavily based on soft information. When a bank becomes part of a larger organisation and a new layer of lending management at the parent bank is introduced, the informational rent of local loan officers increases considerably, as well as the agency costs associated with small business lending. Thus, it is likely that the acquiring bank will follow an intense APCS.

Therefore, we argue that in acquisitions involving banks headquartered in backward Italian Southern regions the ACS goes along with strong APSs, indeed the latter often tend to dominate. To test for this conjecture, we split the dummy variable for South in equation (1) into three variables for young acquired, old acquired and autonomous banks located in Southern regions:

$$
\begin{aligned}
y_{i t}= & \alpha+\beta_{1} y_{i t-1}+\beta_{2} \text { SIZE }_{i t}+\beta_{3} \text { MARKET POWER }_{i t} \\
& +\beta_{4} \text { SOUTHERN YOUNG ACQUIRED }_{i t}+\beta_{5} \text { SOUTHERN OLD ACQUIRED }_{i t} \\
& +\beta_{6} \text { SOUTHERN AUTONOMOUS }_{i t}+\lambda_{i}+\phi_{t}+\varepsilon_{i t}
\end{aligned}
$$


where variables with the same label as shown in equation (1) maintain their meaning; the new dummy variables are described below. In equation (2) all types of non cooperative banks located in the Northern and Central Italian regions are the benchmark category.

In table 2 we report the expected signs of coefficients, consistent with ACS, APRS and APCS respectively. Following our empirical strategy, the dominance of ACS over APS (APS over ACS) occurs when the estimated coefficient for young acquired banks is statistically significant (not significant) and the estimated coefficient for old acquired banks is not statistically significant (significant). With regard to the type of portfolio strategy, the findings of our models can only eventually exclude the presence of a successful APRS, while they cannot be conclusive in the case of APCS.

\section{[Insert table 2]}

Before considering the econometric analysis, it is important to note that our empirical strategy and results are subject to three inescapable caveats. The first caveat is that our conjectures are based on the expected effects of asset restructuring strategies on banks' returns. However, we can only observe the current banks' profitability. This implies that, in principle, the absence of improvements in the current profitability of the acquired bank cannot exclude that the restructuring strategy actually followed by the acquirer is an APRS.

The second caveat is that misallocations and changes in the structure of costs and revenues are not a one-time occurrence. This implies that asset restructuring strategies requested to tap inefficiencies may also change over time. Therefore, what we observe and interpret to be long-term effects could actually be the short-term effects of a successful asset restructuring strategy implemented some years after the acquisition and not ascribable to it.

Similarly, restructuring strategies may also occur in the asset portfolio of non-acquired (autonomous and merged) banks. If this were the case, the estimated coefficients of our "young and old acquired bank" variables may underestimate the effects of restructuring strategies of the acquired banks. However, we should remember that the estimated coefficients of dummy variables 
are "differential intercept coefficients" because they tell us by how much the value of the intercept that receives the value of 1 differs from the intercept coefficient of the benchmark category (i.e., the asset restructuring strategies followed by other banks). Therefore, the results of our regressions must be read comparatively, as the observed effects of asset restructuring strategies associated with acquisitions compared with those carried out by other banks.

\section{Data, variables and econometric methodology}

Our unbalanced panel data includes Bank of Italy information on bank conditions (independence or affiliation to a BHC) and bank branch locations, and selected bank balance-sheet variables extracted from the Bilbank dataset provided us by the Italian Banking Association, A.B.I. (Rome).

Information on banks runs from 1993 through 2003; however, given the way the "old affiliated" variable is built, we are left with a complete information set only for the period 19962003. The number of banks $(N)$ ranges from 588 and 691 . The number of observations $(N \times T)$ employed for each estimate is reported in table 4 and ranges from 2084 and 3090. The estimation period is 1997-2003 for the income fees and the Roa equations, but 1998-2003 for the loans to small business, loans to companies and Roe equations. These differences occur either because the time lag of instruments is not the same for all equations, or information on selected balance sheet items is unavailable for some years.

Each of our estimates includes all commercial and cooperative banks and excludes bank association clearing houses, due to their specific status.

Based on the discussion carried out in section 3 we constructed three asset allocation and two profitability dependent variables. The first two asset allocation variables are the shares of loans to small businesses (Loan_sb) and to companies (Loan_comp). They are calculated as the ratio of loans to family businesses and to other non financial companies to total loans, respectively.

Italian family businesses are very small-sized companies that are requested to disclosure little formal information. Traditionally, their financial sources are cash-flow and bank loans. The 
relationship between banks and family businesses is usually built upon soft information and reciprocal personal acquaintance between the local loan officer and the entrepreneur, plus the provision on the part of the latter of collateral in the form of family wealth (bonds, houses, etc.). Therefore, it is often the case that small business loans are not subject to close screening and result unworthy ex-post. Diversely, providing loans to larger companies requires close screening and banks devote more resources to determining the expected profitability of their investment projects. Therefore, loans to family businesses and to other companies should respond in a different way to acquisitions according to the type of restructuring strategy undergone by the acquiring bank.

The third asset allocation variable is the ratio of net income fees to gross operating income. Elsewhere, in Calcagnini (2003), it has been already noted that increases in this ratio occurred among the most dynamic Italian banks that expanded their provision of financial services, both in the traditional field of asset management and in the more innovative corporate finance and investment banking areas. Therefore, differences in the ratio of net income fees to gross operating income will signal the existence of different asset strategies between autonomous and acquired banks.

The last two dependent variables are measures of bank profitability, the Return on assets (Roa) and the Return on equity (Roe). They are constructed as the ratio of banks' profits after taxes to total assets and bank equity, respectively. The Roa measures the bank's capacity to remunerate its assets; therefore, it is more suitable to compare banks' ability to successfully invest in the most profitable assets. The Roe measures the bank's capacity to remunerate its owners' investment. In a competitive environment both profitability ratios should reflect an identical picture of the ability of bank management to efficiently allocate their portfolio. Diversely, differences in the Roa and the Roe observed between autonomous and acquired banks may be the result of different asset restructuring strategies. 
As for the explanatory variables, we constructed four control variables and two asset restructuring strategy variables for model (1), and three control variables and three asset restructuring strategy variables for model (2).

Both in model (1) and (2) we introduced controls for the bank's size, its market power and localism. Bank size is measured by the log of banks' total assets. We could have used other measures of bank size (number of employees, number of branches, the log of total loans, etc.), but we kept in line with other empirical analyses that use total assets as the preferred measure of banks' size.

The Market Power variable is the average share of branches that each bank owns, solely in provinces where it is present:

$$
(\text { Market Power })_{i}=\frac{\sum_{j=1}^{P_{i}} \frac{\text { branches }_{i j t}}{\text { branches }_{j t}}}{P_{i}}
$$

where $i$ indicates the bank, $j$ the province and $P_{i}$ the number of provinces where bank $i$ operates as of the beginning of time $t$. This measure of market power puts more emphasis on local market power than on other alternative measures. In fact, Market Power takes into account that a small local bank may have more market power than a large national bank because, in the few provinces where it is present, it has on average a larger share of branches. We opted for this measure of market power because in Italy provincial markets are still relatively separated one from the other and localism plays an important role in the way banks and firms interact.

The local character of the bank is measured by a dummy variable that takes on a value of 1 if the bank is a cooperative bank. Equation (1) also controls for the regional location of banks' headquarters. Specifically, in equation (1) we introduced the dummy variable South that takes on the value of 1 if the bank's headquarters are in a Southern region and 0 otherwise.

As for the asset restructuring strategy variables, we constructed dummy variables controlling for the acquired status of banks. Moreover, to disentangle short- and long-run effects of asset restructuring strategies in our dependent variables we distinguish "young" from "old" acquired 
banks on the basis of the date of the acquisition deal. Specifically, following prior research (Berger et al. 1998; Focarelli et al. 2002), long-run effects allow for three years after the acquisition deal. So, in equation (1) Young Acquired Bank takes on the value of 1 in three years following the acquisition and 0 otherwise; whereas Old Acquired Bank takes on a value of 1 in all years after the third one since its acquisition and 0 otherwise.

In equation (2), we concentrate the analysis on acquisitions of Southern banks. Therefore we split the South variable into three different dummies: (i) Southern Autonomous Bank that takes on values of 1 for independent and parent banks headquartered in Southern regions; (ii) Southern Young Acquired Bank that takes values of 1 for acquired banks headquartered in Southern regions in the three years following their acquisition; (iii) Southern Old Acquired Bank that takes values of 1 for acquired banks headquartered in Southern regions in all years after the third from their acquisition. The simultaneous presence of the three dummy variables allows us to identify both differences between Southern banks and all other banks located in the Northern and Central regions, as well as the way in which the asset allocation of Southern autonomous and acquired banks differ as a consequence of asset restructuring strategies.

Finally, each regression includes a number of time dummy variables equal to the number of sample years minus 1 , because of the contemporaneous presence of the intercept in each equation.

The econometric methodology applied to models described in section 3 is nowadays well known - and widely employed - as Dynamic Panel Data Models. In dynamic panel data models the OLS estimator is biased due to correlation of the lagged dependent variable with the individual specific effects. Since in equations (1) or (2) $y_{i t}$ is a function of $\lambda_{i}, y_{i t-1}$ is also a function of $\lambda_{i}$. Therefore $y_{i t-1}$, a right-hand regressor, is correlated with the error term. This renders the OLS estimator biased and inconsistent, even if the $\varepsilon_{i t}$ are not serially correlated. This holds whether the individual effects are considered fixed or random.

Arellano and Bover (1995) and Blundell and Bond (1999) suggested a "system GMM" estimator to overcome the coefficient bias; this estimator is now fully implemented as one of the 
Stata econometric package commands (i.e., xtabond2). All our models are estimated by means of the xtabond 2 command with the exception of the Roe equation. Indeed, we were unable to find a specification for the Roe equation that passed the Hansen test of overidentifying restrictions. Given that we were interested in analyzing differences in bank profitability when it changes its status from being autonomous to acquired, but also differences between groups of banks defined on the basis of characteristics that did not change during our estimation period (like banks' regional location or status), we estimated the Roe equation in levels and used the lagged first differences of the return on equity and employees-per-bank-branch ratio as instruments. Even though this approach may not be efficient because of the presence of the lagged dependent variable among the regressors, estimated coefficients of the dummy variables were the same as in the case of the "system GMM" estimator and the random effects estimator. ${ }^{3}$

\section{Results}

\subsection{Descriptive statistics}

Descriptive statistics reported in table 4 show differences in the way types of banks allocate their portfolio and their profitability. Acquired banks allocate, on average and with respect to autonomous banks, similar shares of their loans to small businesses and to other non financial companies. In the same way, acquired and autonomous banks earn an identical share of operative income from non-lending activities. As for profitability, however, acquired banks appear able to have higher returns than other banks, although the variability of returns among acquired banks is also higher. In particular, there appear to be larger differences between acquired banks and autonomous banks when the Return on equity is considered, whereas the Roa increases only for Old Acquired Banks.

\section{[Insert table 4]}

\footnotetext{
${ }^{3}$ These results are not shown in tables 5 and 6 , but are available upon request from the authors.
} 
There are, instead, pronounced differences between the two groups of banks (acquired and autonomous) headquartered in the Mezzogiorno. Acquired banks make a lower share of loans to small businesses, and a larger share of loans to other non-financial firms than do autonomous banks. This is to be expected, according to what we labelled the asset cleaning strategy of the acquiring bank. However, Southern acquired banks also show a larger proportion of income from fees and, above all, their asset allocation does not converge over time towards that of autonomous banks. This suggests that, consistent with our APSs, the changes in asset portfolios are permanent. Finally, Southern acquired banks show lower profitability rates than Southern autonomous banks. According to our empirical strategy, this fact means that in the case of Southern bank acquisitions, acquiring banks did not confine themselves to adjusting the pre-acquisition asset misallocation of target banks (that is, to what we labelled APRS), but probably also introduced changes in lending policies.

Cooperative banks are small-sized and particularly widespread in the Northern-Eastern Italian regions. The median cooperative bank in our sample has total assets that are around $6 \%$ of the median commercial bank's. The former specialize in the provision of small loans and more traditional services to customers. Thanks to their size, cooperative banks often operate in market niches, and are able to extract rents from their customers. Therefore, their profitability is also the highest. These characteristics are clearly reflected in the averages of the five variables shown in table 4.

\subsection{Regression analysis}

Tables 5 and 6 show econometric estimation results for equations (1) and (2), respectively. First of all, we note that all specifications pass the tests most frequently cited in the dynamic panel-data literature. The Hansen test of over identification restrictions accepts the null in all cases; moreover, the presence of negative first-order serial correlation is correctly detected in differenced residuals, 
but there is no evidence of second-order serial correlation. Furthermore, all the dependent variables follow a first-order autoregressive process; consequently the use of the GMM estimator is required.

\section{A. Control variables}

Let us start by considering the control variables. Since the estimated coefficients of these variables do not change significantly between models (1) and (2) (see tables 5 and 6), we will comment upon them all together.

Bank size strongly affects both credit allocation and profitability. Firstly, we find confirmation of the hypothesis of bank specialization in the provision of loans, given that the percentage of small business lending is negatively correlated with bank size (see above, section 2A.). By contrast, large banks tend to commit a higher share of their total loans to other companies and earn higher income from non-lending activities. Finally, we find that bank size has a beneficial effect on profitability, particularly when measured in terms of Roe.

With regard to Market Power, consistent with the information-based literature on competition and credit allocation (Petersen and Rajan 1995; Gehrig 1998) and with some recent findings for Italy (Bonaccorsi and Gobbi 2001; Bonaccorsi and Dell'Ariccia 2001), we find that banks with a higher degree of market power lend more to small and possibly more opaque firms, whereas they reduce their transactional non-lending activities. Small-sized firms traditionally favor relationships with local banks, that often have significant market power in local markets ${ }^{4}$. Indeed, during the Nineties, local banks with a certain amount of initial market power were able to impose sufficient costs on potential entrants to induce lower rates of branching than in other more contested markets (Calcagnini and Hester 2002). Moreover, the increasing integration of credit markets represented an incentive for local credit institutions to expand relationship-based loans with the purpose of exploiting profits from their informational rents and insulating small businesses from competition from outside lenders (Boot and Thakor 2002; Dell'Ariccia and Marquez 2004).) Consistent with the

\footnotetext{
${ }^{4}$ Recall that market power was calculated as the average value of the bank's market share in terms of branches in the provinces where it operates.
} 
Hicksian "quiet-life" hypothesis, however, the degree market power does not appear to be correlated with banks' profitability.

The importance of private information and group interactions for small business lending is confirmed by the estimated positive coefficient for cooperative banks in the Loan_sb regression. This finding is consistent with previous related results for Italy (Angelini et al. 1998). It may be justified both by cooperative banks' superior access to local information and by group incentives due to their ownership status that facilitate the screening and monitoring of borrowers (Rasmusen 1998; Banerjee et al. 1994). Interestingly, the greater commitment of cooperative banks to small firms is not at the expense of loans to other non-financial companies, but of non-lending activities, and has positive effects on their profitability.

Finally, as we expected, for banks headquartered in less developed Southern regions, where small-sized companies are comparatively more numerous than in Northern and Central regions, small business lending is relatively greater compared to that carried out by banks in other regions. By contrast, as a consequence of the less economically developed nature of the Mezzogiomo, Southern banks lend significantly less to other non-financial firms, enjoy lower non-lending activities and have a lower profitability than Central-Northern banks.

\section{[Insert tables 5 and 6]}

\section{B. Asset restructuring strategies in banking acquisitions}

When we analyse banks' asset restructuring strategies, our regression analysis shows, consistent with the univariate analysis of section 5.1, that the asset portfolio of acquired banks undergoes some temporary adjustments after the acquisition deal which, however, are not confirmed in the long-run.

Specifically, estimation results of equation (1) show that becoming part of a bank holding group means a clean sweep of opaque loans in the early years after the acquisition date, as shown by the negative coefficient of the "Young Acquired Bank" dummy variable. However, after three years from the date of acquisition, the share of loans that acquired banks allocate to small businesses is as 
large as that of other banks. Indeed, the coefficient of the "Old acquired" dummy variable is not statistically significant. This result suggests that banks' restructuring strategies are more directed at cleaning out unworthy loans than to changing the acquired banks' asset portfolio.

This conclusion is confirmed by the regressions for the share of loans to other non-financial firms and by net fees earned from services. In both cases, acquisition does not entail any permanent change in the asset allocation of the acquired bank. Interestingly, acquired banks do not reduce loans to companies even in the short run. It is likely that, because banks invested more resources in the selection of larger projects than in those provided to small family businesses, the average quality of loans to other non-financial firms is higher than that of loans to small businesses. Thus, no restructuring was needed once the acquired bank entered the acquirer's bank holding group.

With regard to the "fees from services" equation, the estimated coefficients of the two dummy variables of interest (Young Acquired Bank and Old Acquired Bank) are not statistically significant, showing that the engagement towards non-lending activities is similar for autonomous and acquired banks.

Regressions results for the Roa and Roe show the positive effects of acquisitions on the profitability of the acquired banks both in the short- and long-run. When read together with results on asset allocation, this finding suggests that acquisitions in Italy were primarily directed at acquiring market power and scale economies on the cost side, whereas on the asset side they continued with a restructuring strategy basically devoted to clean sweeping erroneous or unlucky loans granted in the past.

\section{Asset restructuring strategies in the acquisition of Southern banks}

The situation changes drastically when we consider asset restructuring strategies in acquisitions involving Southern banks. Overall, in this case the effects of acquisitions on the asset allocation of acquired banks are permanent rather than temporary. 
The asset allocation of acquired banks headquartered in the South, particularly for the "old acquired" banks, appears systematically different from that of autonomous banks headquartered in the same area. First, while the coefficient for Southern Autonomous Banks in the Loan_sb equation is statistically significant and positive, the coefficients of Southern Young Acquired Bank and Southern Old Acquired Bank are not statistically significant (table 6, column 1). This suggests that Southern banks, once acquired, reduce the proportion of lending to small businesses to levels statistically equal to those of Central-Northern banks.

Second, a similar but opposite dynamics concerns the proportion of loans to other nonfinancial firms (table 6, column 2). Autonomous banks headquartered in the South grant a smaller share of their loans to non-financial firms than banks outside the Mezzogiorno. Soon after the acquisition deal, Southern acquired banks increase this proportion, but it takes longer than three years before their share of loans to non-financial firms becomes non-statistically different from that of banks located in Northern and Central regions.

Third, acquisitions of Southern banks seem to go along with an increase in the service activities of acquired banks (table 6, column 3). Again this effect occurs in the long-run. Southern young acquired banks, as well as autonomous banks, earn a lower share of their income from non-lending financial services than banks headquartered outside the Mezzogiorno. It is only after the three-year period that there seems to be no significant differences between the share of income due to net fees of the Southern "old acquired" banks and of other banks in the Northern and Central regions

Therefore, in the case of acquisitions of Southern banks, we have strong empirical evidence in favour of APSs. In turn, this conclusion might suggest that Southern banks not only make more incorrect lending decisions and operate with riskier borrowers than other banks, but they seriously misallocate their asset portfolio. To test for the pre-acquisition misallocation hypothesis, we look at the profitability of acquired banks. Indeed, if before the acquisition Southern banks were really misallocating their portfolio, and the APSs of the acquirer banks were aimed at improving this allocation, the profitability of acquired banks should increase after the acquisition. 
Econometric results for the "Return on assets" equation and for the "Return on equity" equation are shown in table 6, columns 4 and 5. With regard the "Roa" equation, the estimated coefficient of the Southern Autonomous Bank is statistically significant and negative, meaning that their profitability is lower than that of other banks. In the case of the Southern Young Acquired Bank and Southern Old Acquired Bank the estimated coefficients are still negative, but not statistically significant. Estimated coefficients of the "Roe" equation strengthen the result of lower profitability for Southern Autonomous Bank, but also show a relative worsening of the acquired banks' profitability both in the short- and long-run 5 .

When read together, these findings cannot unambiguously corroborate the pre-acquisition misallocation hypothesis. Even if the time span of our analysis may be not long enough to allow for the positive effects of APRSs on profitability to fully manifest themselves, the presence of an APCS cannot be safely excluded in the case of Southern banks' acquisitions. What we likely observe is that Southern banks, once part of the holding group undergo a restructuring of their portfolios to conform to the new specialization model of the acquiring bank. Moreover, lending relationships in economically backward regions are heavily based on soft and very localized information, in the hands of local managers of the acquired banks. The presence of the strong informational rents and the large agency costs associated with small business lending may induce the acquiring banks to pursue an APCS in favour of transactional activities, at the expense of small and opaque borrowers.

\section{Conclusions}

In this paper we have focused on the asset restructuring strategies pursued by the acquiring banks after the acquisition of the majority of shares of another bank. We distinguished three different asset restructuring strategies, labelled as ACS (asset cleaning strategy), APRS (asset portfolio reassessment strategy) and APCS (asset portfolio consolidating strategy). Then, we tried to empirically evaluate their

\footnotetext{
${ }^{5}$ Of course, a possible simple accounting reason for which the Roe of the Southern acquired banks is relatively lower than that of other banks is that their equity-to-assets ratio was increased following the acquisition deal to a higher level than Southern autonomous banks. Indeed, for the Southern acquired banks the average ratio of equity to total assets, between 1997 and 2003, was $12.2 \%$. In the same period of time, the ratio of equity to total assets for Southern autonomous banks was $10.1 \%$.
} 
primacy by analysing the impact on asset allocation and on expected returns of the acquired banks. In our approach, these effects may vary on the basis of three discriminating factors. The first one is the time profile of the acquisition. The underlying assumption is that each new strategy activates a dynamic process that can produce its effects in more or less time according to its complexity. The second one is the location of acquired banks. From this point of view, we have tested if -- and to what extent -- the impact of the asset restructuring policies could differ when target banks are located in peripheral backward regions. The third discriminating factor concerns the independence of banks, that allows us to discern if the acquired banks behave differently than the non-affiliated banks, and -- in the affirmative case - in which strategy.

We have tested hypotheses on bank asset restructuring strategies by means of a large dataset covering the period 1993-2003. The considerable number of acquisitions and the prevalent localization of acquired banks in the less developed Southern regions lends particular relevance to our case-study. The main results can be summarized as follows.

First of all, our estimates confirm the different features, both in asset allocation and in profitability, that we should expect for all banks, affiliated or not, according to their size, market power, and location. Larger banks lend relatively less to small businesses and more to other companies; their profitability is higher and is more affected by net income from services. Market power positively influences the share of small lending, but at the expense of reducing income from services. This result is particularly evident for cooperative banks, that in any case remain more profitable. The banks located in the backward regions of the South, where firms are smaller and riskier, lend more to small businesses than to other companies, earn less income from services, and remain less profitable.

A second set of results concerns the asset cleaning strategy, which is most likely the first intervention that the acquiring bank makes, aimed at cleaning unworthy loans in the portfolio of the target bank. It is reasonable to expect that this action impacts to a great extent on the share of riskier lending to small and informational opaque borrowers. In line with this assumption, our 
econometric estimates provide strong evidence that this strategy was adopted only by young acquired banks, that are less likely to lend to small businesses. This cleaning of unworthy loans is temporary, since old acquired banks, after more than three years from their acquisition, do not show a share of small lending statistically different than other banks. Moreover, our results show that bank acquisitions had a permanent positive impact on the profitability of acquired banks, but also resulted in no remarkable change on asset portfolio allocation in the long run.

These empirical findings drive us to conclude that, in the Italian experience, bank acquisitions had been mainly oriented to asset cleaning strategies in the short run, and to consolidating increased profitability in the long run. The fact that this result was obtained with no relevant changes in the asset portfolio allocation could be interpreted in different ways. One possible way puts emphasis on the advantages of profitability obtained mainly from the cost side, that could have been accompanied by more banking power once the acquired bank becomes part of larger groups. Another plausible interpretation follows from the consideration that the need to restructure asset portfolios was lowered by the substantial similarity in lending strategies of target banks and of acquiring banks. This is most likely to happen in developed regions, where the organizational structure and the performance of banks are functionally more advanced and less distant (Alessandrini et al. 2005). From this point of view, our national level results can be interpreted as predominantly influenced by acquisitions that involved banks operating in the more developed Central-Northern regions of Italy.

The final set of our findings is dedicated to the banks headquartered in the Southern regions. It is not surprising that the econometric estimates herein are in contrast with the results obtained at the national level, but consistent with our conclusions in the previous paragraph. The acquisitions of banks located in the South were mainly realized by banks located in the Centre-North, that are economically and functionally more distant. It follows that, given the dissimilarity of banks in the two areas, the portfolio reallocation of the acquired bank becomes necessary. However, this is a very complex task that requires considerable time to be successfully implemented. 
Our results confirm this assumption. In the South, the asset restructuring strategies of acquired banks is systematically different from that of autonomous banks, but the behaviour of the former tends to progressively become similar to that of banks located in the Northern and Central regions. The empirical evidence reveals that acquiring banks aimed at permanently modifying the asset allocation of the target banks, while they implemented short-run asset cleaning strategies in their Southern affiliated banks; this is in line with what we observed at the national level. We have attempted the difficult task of identifying which one of the two portfolio strategies, that could determine considerable changes in the asset allocation after acquisition, predominates. On one hand, there is the asset portfolio reassessment strategy, that implies an intervention to correct the mismanagement in the asset allocation of the acquired bank, without changing its optimal distribution. On the other hand, the asset portfolio consolidating strategy exists, that implies a more radical change in the optimal distribution of assets, closer to the lending policy of the parent bank. The results we have obtained only allow us to formulate our conclusions indirectly. While we cannot confirm the APRS assumption, we cannot exclude the possibility that the APCS assumption prevailed. The question remains open to further empirical investigation. 


\section{References}

Alessandrini P., L. Papi and A. Zazzaro (2003). "Banks, regions and development", Banca Nazionale del Lavoro Quarterly Review, 224, 23-55.

Alessandrini, P., M. Croci, A. Zazzaro (2005), “The geography of banking power: the role of functional distance”, Banca Nazionale del Lavoro Quarterly Review, 235, 129-67.

Angelini P., R. Di Salvo and G. Ferri (1998), "Availability and cost of credit for small businesses: Customer relationships and credit cooperatives", Journal of Banking and Finance, 22, 925-54.

Arellano, M. and S.R. Bond (1991), "Some Tests of Specifications for Panel Data: Monte Carlo Evidence and an Application to Employment Equations", Review of Economic Studies, 58, 277297.

Banca d'Italia (2005), Annual Report 2004, Rome, Bancad'Italia.

Banerjee A.V., T. Besley and T.W. Guinanne (1994), "The neighbor's keeper: The design of a credit cooperative with theory and a test", Quartely Journal of Economics, 109, 491-515.

Berger A.N. and G.F. Udell (1998), "The economics of small business finance: The roles of private equity and debt markets in the financial growth cycle", Journal of Banking and Finance, 22, 613-73.

Berger A.N. and R. DeYoung (2001), "The effects of geographic expansion on bank efficiency", Journal of Financial Services Research, 19, 163-84.

Berger A.N. and R. DeYoung (2002), “Technological progress and the geographic expansion of the banking industry", Federal Reserve Bank of Chicago, WP 2002-07.

Berger A.N., A. Saunders, J.M. Scalise and G.F. Udell (1998), “The effects of bank mergers and acquisitions on small business lending", Journal of Financial Economics, 50, 187-229.

Berger A.N., N.H. Miller, M.A. Petersen, R.G. Rajan and J.C. Stein (2005), "Does function follow organizational form? Evidence from the lending practices of large and small banks", Journal of Financial Economics, 76, 237-69.

Berger, A.N. and G.F. Udell (1998), "The effects of bank mergers and acquisitions on small business lending", Journal of Financial Economics, 50, 187-229.

Berger, A.N. and G.F. Udell (2002), "Small business credit availability and relationship lending: The importance of bank organizational structure", Economic Journal, 112, F32-F53.

Blundell, R. and S. Bond (1998), "Initial conditions and moment restrictions in dynamic panel data models", Journal of Econometrics, 87, 115-43.

Banca d'Italia (2005), Relazione annuale sul 2004, Rome: Banca d'Italia.

Bonaccorsi di Patti E. and G. Dell'Ariccia (2001), "Bank competition and firm creation", IMF working paper, No. 21.

Bonaccorsi di Patti E. and G. Gobbi (2001), "The changing structure of local credit markets: Are small business special?", Journal of Banking and Finance, 25, 2209-37. 
Bonaccorsi di Patti E. and G. Gobbi (2003), "The effects of bank mergers on credit availability: Evidence from corporate data", Banca d'Italia, Temi di discussione, No. 479.

Boot A.W.A. A.V. Thakor (2000), "Can relationship banking survive competition?”, Journal of Finance, 55, 679-713.

Calcagnini, G. and D. D. Hester (2002), Banking Changes in the European Monetary Union. An Italian Perspective, Roma: Carocci.

Calcagnini G. (2003), "L'evoluzione del sistema bancario italiano negli anni novanta” in M. Messori, R. Tamborini e A. Zazzaro (eds), Il sistema bancario italiano, Roma: Carocci.

Dell'Ariccia G. and R. Marquez (2004), “Information and bank credit allocation”, Journal of Financial Economics, 72, 185-214.

European Central Bank (2000), "Mergers and acquisitions involving the EU banking industry. Facts and implications", December.

European Central Bank (2005), "EU Banking structures”, October.

Focarelli D., F. Panetta and C. Salleo (2002) "Why do banks merge?”, Journal of Money Credit and Banking, 34, 1047-66.

Gehrig T. (1998), "Screening, cross-border banking, and the allocation of credit", Research in Economics, 52, 387-407.

Goldberg L.G. and L.J. White (1998), "De novo banks and lending to small businesses: An empirical analysis", Journal of Banking and Finance, 22, 851-67.

Houston J.F. and C. James (1998), "Do bank internal capital markets promote lending?”, Journal of Banking and Finance, 22, 899-918.

Keeton W.R. (1995), "Multi-office bank lending to small businesses: Some new evidence”, Federal Reserve Bank of Kansas City Economic Review, Second Quarter, 45-57.

Keeton W.R. (1996), "Do bank mergers reduce lending to businesses and farmers? New evidence from tenth district States", Federal Reserve Bank of Kansas City Economic Review, Third Quarter, 6375.

Klein P.G. and Saidenberg (2005), "Organizational structure and diversification discount: Evidence from commercial banking”, University of Missouri, CORI working paper, No. 6.

Liberti J.M. (2004), "Initiative, incentives and soft information. How does delegation impact the role of bank relationship managers?”, mimeo, London Business School.

Liberti J.M. (2005), "How does organizational form matter? Communication, distance and soft information", mimeo, London Business School.

Messori M. and A. Zazzaro (2003), "Aggregazioni bancarie, riassetti proprietary e modelli di governo. Come sono cambiate le banche negli anni Novanta”, in M. Messori, R. Tamborini e A. Zazzaro (eds), Il sistema bancario italiano, Roma: Carocci. 
Meyer M., P. Milgrom, J. Roberts (1992), “Organizational prospects, influence costs and ownership changes", Journal of Economics and Management Strategy, 1, 9-35.

Milgrom P. (1988), "Employment contracts, influence activities, and efficient organization design", Journal of Political Economy, 96, 42-60.

Milgrom P. and J. Roberts (1990), "Bargaining costs, influence costs, and the organization of economic activity", in J. Alt, K. Shepsle (eds.), Perspective on positive political economy, Cambridge: Cambridge University Press, 57-89.

Nakamura L. (1994), "Small borrowers and the survival of the small banks: Is the mouse banks Mighty or Mickey?”, Federal Reserve Bank of Philadelphia Business Review, Nov.-Dec., 3-15.

Novaes W., L. Zingales (2004), "Bureaucracy as a mechanism to generate information”, Rand Journal of Economics, 35, 245-59.

Petersen M.A. and R.G. Rajan (1995), "The effect of credit market competition on lending relationships", Quarterly Journal of Economics, 110, 407-43.

Rasmusen E. (1988), "Mutual banks and stock banks", Journal of Law and Economics, 31, 395-421.

Sapienza P. (2002), "The effects of banking mergers on loan contracts”, The Journal of Finance, 57, $329-67$.

Stein J. (2002), "Information production and capital allocation: Decentralized versus hierarchical firms", Journal of Finance, 57, 1891-921.

Strahan P.E. and J.P. Weston (1998), "Small business lending and the changing structure of the banking industry", Journal of Banking and Finance, 22, 821-45.

Udell G.F. (1989), "Loan quality, commercial loan review and loan officer contracting", Journal of Banking and Finance, 13, 367-82.

Whalen G. (1995), Out-of-state holding company affiliation and small business lending. Economic and policy analysis", Comptroller of Currency Working Paper, No. 4. 
Table 1: The effects of restructuring strategies on asset allocation and expected returns of the acquired bank

\begin{tabular}{|c|c|c|c|c|c|c|}
\hline & \multicolumn{2}{|c|}{ Asset cleaning strategy } & \multicolumn{2}{c|}{$\begin{array}{c}\text { Asset portfolio } \\
\text { reassessment strategy }\end{array}$} & \multicolumn{2}{|c|}{$\begin{array}{c}\text { Asset portfolio } \\
\text { consolidating } \\
\text { strategy }\end{array}$} \\
\hline & $\begin{array}{c}\text { Changes in } \\
\text { asset } \\
\text { allocation }\end{array}$ & $\begin{array}{c}\text { Changes in } \\
\text { expected } \\
\text { returns }\end{array}$ & $\begin{array}{c}\text { Changes in } \\
\text { asset } \\
\text { allocation }\end{array}$ & $\begin{array}{c}\text { Changes in } \\
\text { expected } \\
\text { returns }\end{array}$ & $\begin{array}{c}\text { Changes } \\
\text { in asset } \\
\text { allocation }\end{array}$ & $\begin{array}{c}\text { Changes } \\
\text { in } \\
\text { expected } \\
\text { returns }\end{array}$ \\
\hline $\begin{array}{c}\text { Short-run } \\
\text { effects }\end{array}$ & YES & UP & NO/YES & NO/UP & NO/YES & $\begin{array}{c}\mathrm{NO} / \mathrm{UP} / \\
\text { DOWN }\end{array}$ \\
\hline $\begin{array}{c}\text { Long-run } \\
\text { effects }\end{array}$ & NO & NO/UP & YES & UP & YES & $\begin{array}{c}\text { NO/UP/ } \\
\text { DOWN }\end{array}$ \\
\hline
\end{tabular}

Table 2: Coefficients' sign consistent with the different asset restructuring strategies

\begin{tabular}{|c|c|c|c|c|c|c|}
\hline & \multicolumn{2}{|c|}{ Asset cleaning strategy } & \multicolumn{2}{c|}{$\begin{array}{c}\text { Asset portfolio } \\
\text { reassessment strategy }\end{array}$} & $\begin{array}{c}\text { Asset portfolio } \\
\text { consolidating } \\
\text { strategy }\end{array}$ \\
\hline & $\begin{array}{c}\text { Asset } \\
\text { allocation }\end{array}$ & Profitability & $\begin{array}{c}\text { Asset } \\
\text { allocation }\end{array}$ & Profitability & $\begin{array}{c}\text { Asset } \\
\text { allocation }\end{array}$ & Profitability \\
\hline $\begin{array}{c}\text { Equation } \\
\text { (1) }\end{array}$ & $b_{5} \neq 0$ & $b_{5}>0$ & $b_{5}=0$ & $b_{5} \geq 0$ & $b_{5}=0$ & $b_{5} \lessgtr 0$ \\
\hline $\begin{array}{c}\text { Equation } \\
b_{6}=0\end{array}$ & $\beta_{4} \neq \beta_{6} \geq 0$ & $b_{6} \neq 0$ & $b_{6}>0$ & $b_{6} \neq 0$ & $b_{6} \lessgtr 0$ \\
(2) & $\beta_{5}=\beta_{6}$ & $\beta_{5}=\beta_{6}$ & $\beta_{4}=\beta_{6}$ & $\beta_{4} \geq \beta_{6}$ & $\beta_{4}=\beta_{6}$ & $\beta_{4} \lessgtr \beta_{6}$ \\
\end{tabular}




\begin{tabular}{|c|c|}
\hline \multicolumn{2}{|r|}{ Dependent variables } \\
\hline Loan_sb & Loans to self-employed households/Total loans ${ }^{\mathrm{a}}(\%)$ \\
\hline Loan_comp & Loans to non financial firms/Total loans ${ }^{\mathrm{a}}(\%)$ \\
\hline Nfees_gi & Net income from fees/Gross income $(\%)$ \\
\hline Roa & Return on assets $(\%)$ \\
\hline Roe & Return on equity $(\%)$ \\
\hline \multicolumn{2}{|r|}{ Control variables } \\
\hline Size & $\log$ (Total assets) as of the beginning of time $t$ \\
\hline Market Power & $\begin{array}{l}\qquad\left(\text { branches }_{i j} / \text { branches }_{j}\right) / \mathrm{P}_{i} \\
\text { where } i \text { indicates the bank, } j \text { the province and } P_{i} \text { the } \\
\text { number of provinces where bank } i \text { operates as of the } \\
\text { beginning of time } t\end{array}$ \\
\hline South & $\begin{array}{c}\text { Dummy variable equal to } 1 \text { if the bank's headquarters } \\
\text { are located in one of the Southern regions and } 0 \\
\text { otherwise }\end{array}$ \\
\hline Cooperative Bank & $\begin{array}{l}\text { Dummy variable equal to } 1 \text { if the bank is a cooperative } \\
\text { banks, and } 0 \text { otherwise }\end{array}$ \\
\hline \multicolumn{2}{|r|}{ Asset restructuring strategy variables } \\
\hline Young Acquired Bank & $\begin{array}{l}\text { Dummy variable equal to } 1 \text { in the three years } \\
\text { following the date of acquisition, and } 0 \text { otherwise }\end{array}$ \\
\hline Old Acquired Bank & $\begin{array}{l}\text { Dummy variable equal to } 1 \text { if the bank was acquired } \\
\text { more than } 3 \text { years ago, and } 0 \text { otherwise }\end{array}$ \\
\hline Southern Young Acquired Bank & $\begin{array}{l}\text { Dummy variable equal to } 1 \text { if the bank was acquired } \\
\text { less than } 3 \text { years ago and its headquarters are located } \\
\text { in one of the Southern regions, and } 0 \text { otherwise }\end{array}$ \\
\hline Southern Old Acquired Bank & $\begin{array}{l}\text { Dummy variable equal to } 1 \text { if the bank was acquired } \\
\text { more than } 3 \text { years ago and its headquarters are located } \\
\text { in one of the Southern regions, and } 0 \text { otherwise }\end{array}$ \\
\hline Southern Autonomous Bank & $\begin{array}{c}\text { Dummy variable equal to } 1 \text { if the independent (i.e. } \\
\text { non-affiliated) bank's headquarters are located in one } \\
\text { of the Southern regions, and } 0 \text { otherwise }\end{array}$ \\
\hline
\end{tabular}

a) Loans to financial institutions are excluded. 
Table 4: Descriptive statistics for dependent variables broken down by type of bank

\begin{tabular}{|c|c|c|c|c|c|c|c|}
\hline & $\begin{array}{c}\text { Autonomous } \\
\text { bank } \\
\text { (excludes } \\
\text { cooperative } \\
\text { banks) }\end{array}$ & $\begin{array}{c}\text { Young } \\
\text { acquired } \\
\text { banks }\end{array}$ & $\begin{array}{c}\text { Old } \\
\text { acquired } \\
\text { banks }\end{array}$ & $\begin{array}{c}\text { Cooperative } \\
\text { Banks }\end{array}$ & $\begin{array}{c}\text { Autonomous } \\
\text { banks in } \\
\text { Southern } \\
\text { regions }\end{array}$ & $\begin{array}{c}\text { Young } \\
\text { acquired } \\
\text { in } \\
\text { Southern } \\
\text { regions }\end{array}$ & $\begin{array}{c}\text { Old } \\
\text { acquired } \\
\text { banks in } \\
\text { Southern } \\
\text { regions }\end{array}$ \\
\hline \multicolumn{8}{|l|}{ Loan_sb } \\
\hline Mean & 10.14 & 9.09 & 8.84 & 19.98 & 23.91 & 10.47 & 12.15 \\
\hline Std deviation & 7.27 & 4.31 & 5.99 & 9.34 & 10.58 & 4.47 & 8.70 \\
\hline $\mathrm{N} * \mathrm{~T}$ & 429 & 146 & 279 & 1286 & 352 & 31 & 37 \\
\hline \multicolumn{8}{|l|}{ Loan_comp } \\
\hline Mean & 52.25 & 52.00 & 53.65 & 40.87 & 26.50 & 43.50 & 45.34 \\
\hline Std deviation & 14.31 & 13.18 & 14.49 & 16.06 & 13.44 & 15.54 & 18.09 \\
\hline $\mathrm{N} * \mathrm{~T}$ & 585 & 189 & 325 & 1991 & 561 & 43 & 44 \\
\hline \multicolumn{8}{|l|}{ Nfees_gi } \\
\hline Mean & 26.96 & 26.29 & 27.02 & 15.42 & 12.77 & 21.05 & 23.92 \\
\hline Std deviation & 10.79 & 9.09 & 9.78 & 5.46 & 6.16 & 7.75 & 5.80 \\
\hline $\mathrm{N} * \mathrm{~T}$ & 559 & 182 & 316 & 1751 & 498 & 40 & 46 \\
\hline \multicolumn{8}{|l|}{ Roa } \\
\hline Mean & 0.50 & 0.49 & 0.56 & 0.85 & 0.56 & 0.33 & 0.39 \\
\hline Std deviation & 0.41 & 0.59 & 0.55 & 0.57 & 0.55 & 0.63 & 0.59 \\
\hline $\mathrm{N} * \mathrm{~T}$ & 545 & 175 & 309 & 1935 & 309 & 37 & 39 \\
\hline \multicolumn{8}{|l|}{ Roe } \\
\hline Mean & 4.80 & 5.65 & 6.17 & 6.47 & 5.92 & 3.89 & 2.42 \\
\hline Std deviation & 3.93 & 4.15 & 5.53 & 3.56 & 5.12 & 2.76 & 5.02 \\
\hline $\mathrm{N} * \mathrm{~T}$ & 413 & 142 & 268 & 1261 & 335 & 29 & 33 \\
\hline
\end{tabular}


Table 5: Dynamic panel-data estimation.

One-step system GMM results of equation (1)

\begin{tabular}{|c|c|c|c|c|c|}
\hline & \multicolumn{5}{|c|}{ Dependent variables } \\
\hline Explanatory variables & Loan_sb & Loan_comp & Nfees_gi $i_{t}$ & Roa & Roe (a) \\
\hline Loan_sb $b_{t-1}$ & $\begin{array}{l}0.310^{* * *} \\
(0.083)\end{array}$ & & & & \\
\hline Loan_compt-1 & & $\begin{array}{l}0.715^{* * *} \\
(0.044)\end{array}$ & & & \\
\hline Nfees_gi $i_{t-1}$ & & & $\begin{array}{c}0.735^{* * *} \\
(0.062)\end{array}$ & & \\
\hline $\mathrm{R} o a_{t-1}$ & & & & $\begin{array}{c}0.159^{* * *} \\
(0.058)\end{array}$ & \\
\hline $\mathrm{Roe}_{t-1}$ & & & & & $\begin{array}{l}0.008^{* * *} \\
(0.002)\end{array}$ \\
\hline Sizet & $\begin{array}{c}-1.527^{* * *} \\
(0.259)\end{array}$ & $\begin{array}{l}0.801^{* * *} \\
(0.270)\end{array}$ & $\begin{array}{l}0.624^{* * *} \\
(0.158)\end{array}$ & $\begin{array}{l}0.032^{* *} \\
(0.013)\end{array}$ & $\begin{array}{l}0.458^{* * *} \\
(0.137)\end{array}$ \\
\hline Market Power & $\begin{array}{l}0.101^{*} \\
(0.060)\end{array}$ & $\begin{array}{l}-0.007 \\
(0.070)\end{array}$ & $\begin{array}{l}-0.084^{*} \\
(0.046)\end{array}$ & $\begin{array}{l}-0.000 \\
(0.004)\end{array}$ & $\begin{array}{l}-0.025 \\
(0.046)\end{array}$ \\
\hline South & $\begin{array}{l}3.329^{* * *} \\
(0.646)\end{array}$ & $\begin{array}{c}-5.527^{* * *} \\
(0.926)\end{array}$ & $\begin{array}{c}-1.355^{* * *} \\
(0.295)\end{array}$ & $\begin{array}{l}-0.086^{* *} \\
(0.040)\end{array}$ & $\begin{array}{l}-0.928^{* *} \\
(0.380)\end{array}$ \\
\hline Young Acquired Bank & $\begin{array}{l}-1.206^{* *} \\
(0.481)\end{array}$ & $\begin{array}{l}-1.042 \\
(1.340)\end{array}$ & $\begin{array}{l}-0.229 \\
(0.421)\end{array}$ & $\begin{array}{c}0.033 \\
(0.057)\end{array}$ & $\begin{array}{l}1.052^{* *} \\
(0.495)\end{array}$ \\
\hline Old Acquired Bank. & $\begin{array}{l}-0.904 \\
(0.562)\end{array}$ & $\begin{array}{c}0.224 \\
(0.648)\end{array}$ & $\begin{array}{l}-0.132 \\
(0.478)\end{array}$ & $\begin{array}{l}0.089^{*} \\
(0.048)\end{array}$ & $\begin{array}{l}1.748^{* * *} \\
(0.589)\end{array}$ \\
\hline Cooperative Bank & $\begin{array}{l}1.772^{* *} \\
(0.744)\end{array}$ & $\begin{array}{c}0.247 \\
(1.015)\end{array}$ & $\begin{array}{l}-2.352^{* * *} \\
(0.631)\end{array}$ & $\begin{array}{l}0.399^{* * *} \\
(0.050)\end{array}$ & $\begin{array}{l}3.195^{* * *} \\
(0.483)\end{array}$ \\
\hline Constant & $\begin{array}{c}24.041^{* * *} \\
(5.519)\end{array}$ & $\begin{array}{c}1.509 \\
(3.961)\end{array}$ & $\begin{array}{l}-0.435 \\
(1.346)\end{array}$ & $\begin{array}{l}-0.096 \\
(0.187)\end{array}$ & $\begin{array}{l}-2.442 \\
(1.994)\end{array}$ \\
\hline Time Dummies & Included & Included & Included & Included & Included \\
\hline F-test & $\begin{array}{c}\mathrm{F}(12,616)= \\
106.86^{* * *}\end{array}$ & $\begin{array}{c}\mathrm{F}(13,690)= \\
448.01^{* * *}\end{array}$ & $\begin{array}{l}\mathrm{F}(13,680)= \\
1188.61^{* * *}\end{array}$ & $\begin{array}{c}\mathrm{F}(13,661)= \\
22.79^{* * *}\end{array}$ & $\begin{array}{c}\mathrm{F}(12,587)= \\
9.16^{* * *}\end{array}$ \\
\hline $\begin{array}{l}\text { Hansen test of over } \\
\text { identification restrictions }\end{array}$ & $\begin{array}{c}\chi^{2}(10)= \\
10.93\end{array}$ & $\begin{array}{c}\chi^{2}(5)= \\
8.15\end{array}$ & $\begin{array}{c}\chi^{2}(9)= \\
8.87\end{array}$ & $\begin{array}{c}\chi^{2}(8)= \\
12.96\end{array}$ & $\begin{array}{c}\chi^{2}(4)= \\
6.95\end{array}$ \\
\hline $\begin{array}{l}\text { Arellano-Bond test for } \\
\text { AR(1) in first differences }\end{array}$ & $z=-2.98^{* * *}$ & $z=-6.24^{* * *}$ & $z=-2.45^{* *}$ & $Z=-2.16^{* *}$ & n.a. \\
\hline $\begin{array}{l}\text { Arellano-Bond test for } \\
\text { AR(2) in first differences }\end{array}$ & $z=0.60$ & $z=-0.13$ & $z=0.98$ & $z=-0.69$ & n.a. \\
\hline $\begin{array}{l}\text { Number of observations: } \\
N^{*} T\end{array}$ & 2140 & 3090 & 2808 & 2964 & 2084 \\
\hline Number of Banks (N) & 616 & 691 & 681 & 662 & 588 \\
\hline Period of time & $1998-2003$ & $1998-2003$ & $1997-2003$ & $1997-2003$ & 1998-2003 \\
\hline
\end{tabular}

Robust Standard Errors are shown in parentheses; $* \mathrm{p}<0.10, * * \mathrm{p}<0.05, * * * \mathrm{p}<0.01$ significance levels, respectively

(a) Equations in levels, only 
Table 6: Dynamic panel-data estimation.

One-step system GMM results of equation (2)

\begin{tabular}{|c|c|c|c|c|c|}
\hline & \multicolumn{5}{|c|}{ Dependent variables } \\
\hline Explanatory variables & Loan_sb & Loan_comp & Nfees_gi $i_{t}$ & Roa & Roe (a) \\
\hline Loan_sb & $\begin{array}{l}0.304^{* * *} \\
(0.082)\end{array}$ & & & & \\
\hline Loan_compt-1 & & $\begin{array}{l}0.760^{* * *} \\
(0.045)\end{array}$ & & & \\
\hline Nfees_gi $i_{t-1}$ & & & $\begin{array}{c}0.730^{* * *} \\
(0.063)\end{array}$ & & \\
\hline Ro $a_{t-1}$ & & & & $\begin{array}{l}0.162^{* * *} \\
(0.058)\end{array}$ & \\
\hline$R o e_{t-1}$ & & & & & $\begin{array}{l}0.008^{* * *} \\
(0.002)\end{array}$ \\
\hline Size ${ }_{t}$ & $\begin{array}{l}-1.532^{* * *} \\
(0.256)\end{array}$ & $\begin{array}{c}0.835^{* * *} \\
(0.275)\end{array}$ & $\begin{array}{c}0.638^{* * *} \\
(0.158)\end{array}$ & $\begin{array}{l}0.031^{* *} \\
(0.013)\end{array}$ & $\begin{array}{l}0.412^{* * *} \\
(0.133)\end{array}$ \\
\hline Market Power & $\begin{array}{l}0.116^{*} \\
(0.060)\end{array}$ & $\begin{array}{l}-0.019 \\
(0.074)\end{array}$ & $\begin{array}{l}-0.086^{*} \\
(0.045)\end{array}$ & $\begin{array}{l}-0.000 \\
(0.004)\end{array}$ & $\begin{array}{l}-0.008 \\
(0.045)\end{array}$ \\
\hline Southern Autonomous & $3.914^{* * *}$ & $-6.275^{* * *}$ & $-1.454^{* * *}$ & $-0.089^{* *}$ & -0.639 \\
\hline Bank & $(0.723)$ & $(0.959)$ & $(0.286)$ & $(0.042)$ & $(0.422)$ \\
\hline $\begin{array}{l}\text { Southern Young Acquired } \\
\text { Bank }\end{array}$ & $\begin{array}{l}-0.457 \\
(0.682)\end{array}$ & $\begin{array}{l}-3.491^{* *} \\
(1.667)\end{array}$ & $\begin{array}{l}-1.684^{* * *} \\
(0.562)\end{array}$ & $\begin{array}{l}-0.122 \\
(0.126)\end{array}$ & $\begin{array}{l}-1.452^{* *} \\
(0.722)\end{array}$ \\
\hline $\begin{array}{l}\text { Southern Old Acquired } \\
\text { Bank }\end{array}$ & $\begin{array}{c}1.347 \\
(1.431)\end{array}$ & $\begin{array}{l}-0.792 \\
(1.491)\end{array}$ & $\begin{array}{l}-0.179 \\
(0.738)\end{array}$ & $\begin{array}{l}-0.023 \\
(0.132)\end{array}$ & $\begin{array}{l}-2.250^{* *} \\
(0.968)\end{array}$ \\
\hline Cooperative Bank & $\begin{array}{l}2.066^{* * *} \\
(0.683)\end{array}$ & $\begin{array}{c}0.677 \\
(1.173)\end{array}$ & $\begin{array}{l}-2.241^{* * *} \\
(0.607)\end{array}$ & $\begin{array}{l}0.363^{* * *} \\
(0.048)\end{array}$ & $\begin{array}{l}2.236^{* * *} \\
(0.406)\end{array}$ \\
\hline Constant & $\begin{array}{c}27.701^{* * *} \\
(4.281)\end{array}$ & $\begin{array}{c}4.715 \\
(4.445)\end{array}$ & $\begin{array}{l}-0.613 \\
(1.283)\end{array}$ & $\begin{array}{l}-0.047 \\
(0.186)\end{array}$ & $\begin{array}{l}-1.023 \\
(1.850)\end{array}$ \\
\hline Time Dummies & Included & Included & Included & Included & Included \\
\hline F-test & $\begin{array}{c}\mathrm{F}(12,616)= \\
103.49^{* * *}\end{array}$ & $\begin{array}{c}\mathrm{F}(13,690)= \\
469.21^{* * *}\end{array}$ & $\begin{array}{c}\mathrm{F}(13,680)= \\
1187.25^{* * *}\end{array}$ & $\begin{array}{c}\mathrm{F}(13,661)= \\
22.27^{* * *}\end{array}$ & $\begin{array}{c}\mathrm{F}(12,587)= \\
10.61^{* * *}\end{array}$ \\
\hline $\begin{array}{l}\text { Hansen test of over } \\
\text { identification restrictions }\end{array}$ & $\begin{array}{c}\chi^{2}(10)= \\
10.27\end{array}$ & $\begin{array}{c}\chi^{2}(5)= \\
7.80\end{array}$ & $\begin{array}{c}\chi^{2}(9)= \\
9.25\end{array}$ & $\begin{array}{c}\chi^{2}(7)= \\
8.70\end{array}$ & $\begin{array}{c}\chi^{2}(8)= \\
12.57\end{array}$ \\
\hline $\begin{array}{l}\text { Arellano-Bond test for } \\
\text { AR(1) in first differences }\end{array}$ & $z=-2.97^{* * *}$ & $z=-6.26^{* * *}$ & $z=-2.47^{* *}$ & $z=-4.22^{* * *}$ & n.a. \\
\hline $\begin{array}{l}\text { Arellano-Bond test for } \\
\text { AR(2) in first differences }\end{array}$ & $z=0.46$ & $z=-0.05$ & $z=0.93$ & $z=-1.24$ & n.a. \\
\hline $\begin{array}{l}\text { Number of observations: } \\
N^{*} T\end{array}$ & 2140 & 3090 & 2808 & 2964 & 2084 \\
\hline Number of Banks (N) & 617 & 691 & 681 & 662 & 588 \\
\hline Period of time & $1998-2003$ & $1998-2003$ & $1997-2003$ & $1997-2003$ & $1998-2003$ \\
\hline
\end{tabular}

Robust Standard Errors are shown in parentheses; $* \mathrm{p}<0.10, * * \mathrm{p}<0.05, * * * \mathrm{p}<0.01$ significance levels, respectively

(a) Equations in levels, only. 